\title{
BLOOD GLUCOSE LEVELS DURING METHOXYFLURANE ANAESTHESIA *
}

\author{
Joel D Gottlueb, M D, And Robert B Sweet, M D
}

HypeRglycaEmia has long been recognized as one of the cheef responses to the metabolic stress of anaesthesid Diethyl ether especially will produce increases in the blood sugar of up to 100 per cent during the first half-hour to 45 minutes of anaesthesia and for this reason its effect on carbohydrate metabolism has been studied extensively ${ }^{1}$ Experiments done on dogs in the 1920 's seemed to indicate that this hyperglycaemia was related to, or caused by, a profound metabolic acidosis which appeared quite early during the admunistration of ether 234 This explanation was widely accepted as applying to man untul Beecher and his co-workers demonstrated that there is no significant metabolic acidosis during the admunistration of ether to adults, although some degree of acidosis does occur in children ${ }^{5}{ }^{6}$ Prior to Beecher's reports, it had been shown in rabbits that both adrenalectomy and spinal anaesthesia producing a $T_{4}$ sensory level would protect against hyperglycaemia during ether anaesthesıa ${ }^{7}$ This observation has been confirmed repeatedly by the use of both local anaesthetics and adrenergic blockung agents ${ }^{8} \otimes$ Today, therefore, it is generally concluded that the hyperglycaemia produced by ether anaesthesia is mostly the result of the liberation of catecholamines ${ }^{10}$

Other general anaesthetics are also capable of puoducung a hyperglycaemic response Cyclopropane anaesthesia in man elicits an increase in the blood sugar "comparable to that induced by ether" according to Greene 11 Reports concerning the effect of halothane are somewhat divergent Some studies have shown no effect on blood sugar during halothane anaesthesia, while other evaluations have shown that there is some hyperglycaemic response to halothane ${ }^{12}$ This, however, as not as great as that seen with ether and cyclopropane ${ }^{13} 14$ It 1 of interest to note that the hyperglycaemia produced by these agents seems to parallel their effect on sympathetuc activity, for, it has been shown that both ether and cyclopropane produce a marked mcrease in the level of circulating catecholamines, while halothane does not ${ }^{15}$

Methoxyflurane combines some of the structural and anaesthetic characteristics of both diethyl ether and halothane, since it is a halogenated methyl ethyl ether Its effect on carbohydrate metabolssm, however, has not yet been studied carefully In one early report of a clinical trial of methoxyflurane in 206 patients the blood sugar was measured in 6 In 3 of these a moderate rise of about $35 \mathrm{mg} \%$ occurred ${ }^{16}$ Another study with dogs indicated that blood sugar was unchanged during spontaneous respiration but decreased with assisted respiration ${ }^{17}$

\footnotetext{
"From the Department of Anesthesiology, The University of Michigan Medical School, Veterans Administration Hospitzl, Ann Arbor, Michigan
} 
The present study reports observations concerning the effect of methoxyflurane anaiesthesia on blood glucose levels in man in order to determine the drug's effect upon carbohydrate metabolssm and sympathetic actıvity

\section{METHOD}

Ten healthy males ranging in age from 28 to 50 years were anaesthetized with methoxyflurane in the following fashion Three patients received pentobarbital $100 \mathrm{mg}$ and scopolamine $04 \mathrm{mg}$ intramuscularly 90 mmutes prior to anaesthesia, and anaesthesia was then induced with intravenous thiopentone 280-360 mg These patients were mamtamed on methoxyflurane, oxygen, and nitrous oxide The other seven patients received only scopolamine $04 \mathrm{mg}$ for premedication 90 minutes before the study was begun These patients then re ceived only methoxyflurane and oxygen for induction and maintenance throughout the course of the experiment In all cases a semi-closed system was used and a total flow of 4 litres per minute was employed ( 2 litres of oxygen and 2 litres of nitrous oxide, or 4 litres of oxygen alone) Blood samples were drawn just prior to the mduction of anaesthesia and at precise 30-minute-intervals thereafter As each blood sample was drawn, the amount of methoxyflurane which had been vaporized in the previous 30 minutes was measured It has been shown previously that each cubic centimetre of methoxyflurane will produce $209 \mathrm{c} \mathrm{c}$ of vapour at room temperature ${ }^{16}$ Using this figure and the known flow of diluent gases the average concentration of methoxyflurane administered to the patient over the preceding 30 minutes was calculated Once anaesthesia was begun all patients exhibited a remarkably stable course, maintaining both pulse and blood pressure well within normal limits This clinical impression seems to be in accord with other large-scale observations on the effect of methoxyflurane on the circulatory system ${ }^{1819}$ Although the patients were maintaned in a light plane of anaesthesia and the concentration of methoxyflurane administered never exceeded 16 per cent, respiration $\$$ were assisted vigorousily throughout in order to prevent the development of any degree of respiratory acıdosis Surgical intervention did not begin in these patients until the experiments had been concluded so that in the seven patients who received only methoxyflurane and oxygen we were able to measure the effect of the anaesthetic agent alone

\section{RESULTS}

We observed that after 30 minutes of anaesthesia the blood glucose level was approximately $85 \mathrm{mg} \%$ and it generally remained near this level throughout the remainder of the experiment (Fig 1) No difference could be detected between the patients who received pentobarbital and thiopentone prior to anaesthesia and those who did not Variatons in the concentrations of methoxyflurane administered were not great in any one patient and did not seem to have any effect on the blood glucose level (Table I) 


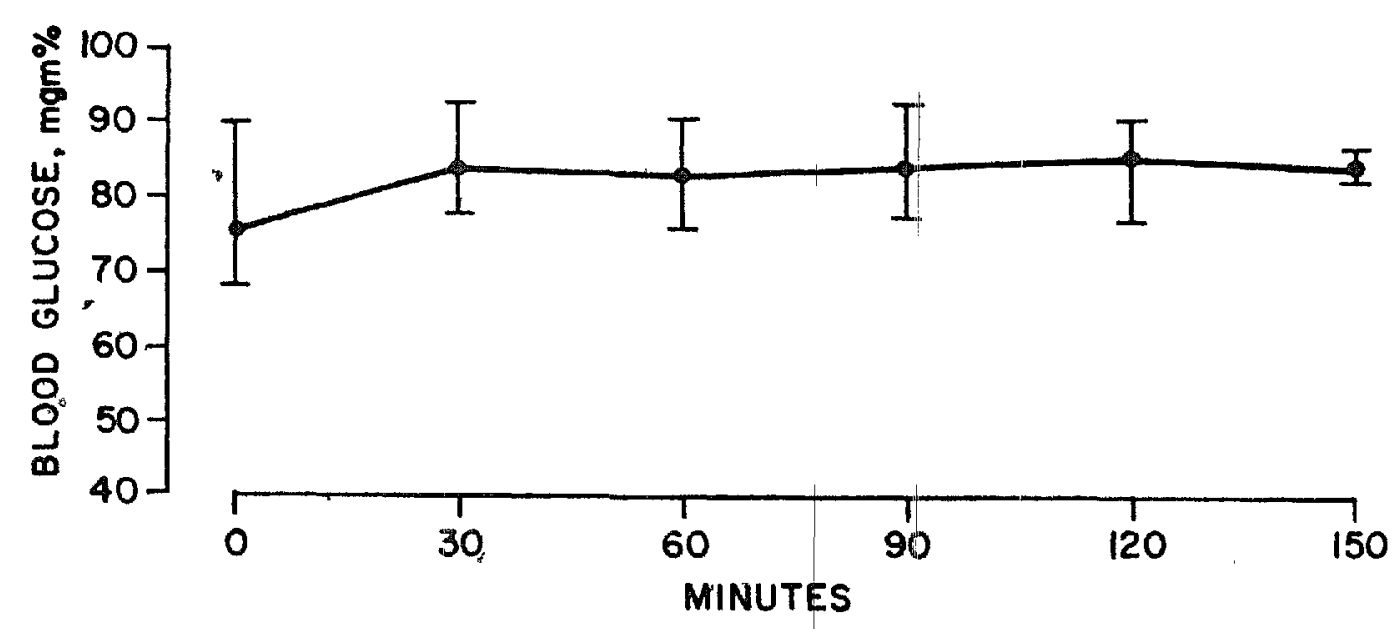

Figure 1 Average valués of blood glucose determmations in 10 patients receiving methoxyflurane anaesthesia. The bars indicate the range of values in each time interval

TABLE I

Blood Glucose Levels in 10 Patients Receiving Methox yflurane Anaesthesia (The first three were premedicated with pentobarbital and received thiopentone for induction, the others recerved only scopolaminè and methoxyflurane)

\begin{tabular}{|c|c|c|c|c|c|c|c|c|c|c|c|}
\hline \multirow[b]{2}{*}{ Patient } & \multirow{2}{*}{$\begin{array}{l}\text { Control, } \\
\text { blood } \\
\text { sugar, } \\
\text { mg \% }\end{array}$} & \multicolumn{2}{|c|}{30 minutes } & \multicolumn{2}{|c|}{60 minutes } & \multicolumn{2}{|c|}{90 minutes } & \multicolumn{2}{|c|}{120 minutes } & \multicolumn{2}{|c|}{150 minutes } \\
\hline & & $\begin{array}{l}\text { Blood } \\
\text { sugar, } \\
\text { mg \% }\end{array}$ & $\begin{array}{c}\% \\
\text { MOF } \\
\text { adm } \\
\end{array}$ & $\begin{array}{l}\text { Blood } \\
\text { sugar, } \\
\text { mg \% }\end{array}$ & $\begin{array}{c}\% \\
\text { MOF } \\
\text { adm }\end{array}$ & $\begin{array}{l}\text { Blood } \\
\text { sugar, } \\
\text { mg \% }\end{array}$ & $\begin{array}{l}\% \\
\text { MOF } \\
\text { adm }\end{array}$ & $\begin{array}{l}\text { Blood } \\
\text { sugar, } \\
\text { mg \% }\end{array}$ & $\begin{array}{c}\% \\
\text { MOF } \\
\text { adm }\end{array}$ & $\begin{array}{l}\text { Blood } \\
\text { sugar, } \\
\text { mg \% }\end{array}$ & $\begin{array}{c}\% \\
\text { MOF } \\
\text { adm }\end{array}$ \\
\hline 1 & 68 & $86^{\circ}$ & 13 & 87 & 07 & 86 & 10 & 87 & 10 & & \\
\hline 2 & 87 & 85 & 08 & 84 & 08 & 85 & 07 & 90 & 08 & & \\
\hline 3 & 75 & 83 & 12 & 82 & 12 & 85 & 10 & 91 & 12 & & \\
\hline 4 & 71 & 81 & 16 & 82 & 10 & 81 & 1.2 & 87 & 12 & 83 & 12 \\
\hline 5 & 90 & 83 & 16 & 78 & 12 & 79 & 10 & 83 & 10 & & \\
\hline 6 & 64 & 82 & 16 & 81 & 10 & 81 & 07 & 80 & 10 & & \\
\hline 7 & 88 & 93 & 15 & 89 & 10 & 93 & 10 & 91. & 07 & & \\
\hline 8 & 71 & 81 & 16 & 80 & 13 & 84 & 07. & 85 & 10 & 87 & 10 \\
\hline 9 & 77 & 88 & 16 & 91 & 08 & 89 & 08 & 88 & 08 & 84 & 10 \\
\hline 10 & 68 & 78 & 16 & 76 & $\begin{array}{l}0 \\
15\end{array}$ & 78 & $\begin{array}{ll}1 & 0 \\
1 & 0\end{array}$ & 77 & $\begin{array}{ll}1 & 0 \\
1 & \end{array}$ & & \\
\hline
\end{tabular}

\section{Discứssion}

The obvious conclusion from these results is that methoxyflurane anaesthesia does not produce any change in blood glucose levels This negative observation has, however, some interesting and important positive corollariẻs The first and most obvious of these is that methoxyflurane in clinically applicable concentrations produces no detectable alteration in carbohydrate metabolısm in so far as such alterations would be reflected in' the blood glucose level While we have not measured other intermediary metabolites it has been found that changes in these metabolites most frequently parallel the changes seen in the blood sugar level, at least during ether anaesthesia ${ }^{10}$ The second corollary to our observation is that methoxyflurane probably does not produce any significant increase in the curculating catecholamines, for as we have said, such an increase is usually reflected in an increased rate of glycogenolysis Of course, a variety of other explanations have been offered for hyperglycaemia during general 
anaesthesia other than an increase in sympathetic activity Studies involving the administration of insulin during ether anae'thesta and in vitro observations on brain tissue seem to indivate that ether may block or uncouple oxidative phosphorylation processes $^{2021} \mathrm{Had}$ we observed an increase in blood sugar during methoxyflurane anaesthesia, we might find it difficult to choose between these explanations as a cause for it In the absence of any such increase it seems safe to conclude that methoxyflurane does not alter sympathetic tone appreciably, does not produce an increase in glycogenplysis, and does not interfere with oxidative phosphorylation processes

\section{SUMMAat}

Blood glucose levels were observed at 30-minute intervals in ten healthy male patients anaesthetized with methoxyflurane It was found that the blood glucose level was approximately $85 \mathrm{mg} \%$ hroughout these anaesthetics It is concluded that methoxyflurane does not interfere with carbohydrate metabolism or alter sympathetic tone in the normal patient

\section{RÉSUMÉ}

La plupart des anesthésiques généraux augmentent la glycémıe Cecı est vraı surtout de l'éther et du cyclopropane Le fluothane, cependant, est moins susceptuble de le fane On a démontré que l'élévation du sucre dans le sang est causée par une augmentation du tonus sympathique Chez 10 malades du sexe masculin qui avaıent reçu du méthoxyflurane comme anesthésıque, on a mesuré le taux du sucre dans le sang, sans observer d'élévation Les concentrations de méthoxyflurane administré allaient de 05 à $16 \%$ On peut conclure que le méthoxyflurane ne trouble pas le métabolisme des hydralles de carbone et qu'il n'est pas sympathicotonique

\section{REFERENCISS}

1 Meme, E \& Miller, H The Effect of Anesthesı, Operation, and Certan Factors on Glycaemia Brit J Med 1244 (1929)

2 VAN SLyKe, D, AUSTIN, J, \& CULlen, G E The Effect of Ether Anesthesia on the Acid-Base Balance of the Blood J Biol Chem 53277 (1922)

3 Leare, C D, Leake, E W, \& Kommler, A E The Acidosis of Ether Anesthesia in the Dog J Biol Chem 56319 (1923)

4. Culle,,$G \mathbb{E}$, Austin J $H$, Kornblum, $K \mathrm{~K}$, \& Robinson, $\mathrm{H} W$ The Inilial Acidosis in Anesthesia J Biol Chem 56 625 (1923)

5 Beecher, H K, Francis, L \& ANFEnsen, L B Metabolic Effects of Anesthesia in Man I Acid-Base Balance during Ether Anesthesia J Pharmacol \& Exper Therap 9838 (1950)

6 Bunger, J P, Brewster, W R, SMith, $\mathbb{R M}$, \& Beccher, $\mathrm{H}$ Metabolic Effects of Anesthesia in Man III Acrd-Base Balance in Infants and Children durng Anesthesia J Appl Physiol 5233 ('1952)

7 Jorinson, $S \mathbb{R}$ The Mechanism is Hyperglycemia during Anesthesia-An Expermmental Study nesthesiology 10379 (1949)

8 Brewster, W $R$ and Bunkrr, J P Metabolic Effects of Anesthesia VI Mechanism of Metabolic Acidosis and Hyperglycemia durng Ether Anesthesia in the Dog Am J Physiol 17137 (1952) 
9 WatTs, Daniel T Inhibition of Ether Hyperglycemıa by Adrenergic Blocking Agents Curr Res in Anesth \& Analg 33343 (1954)

10 Drucker, W $R$, Costley, C , Stufts, $R$, Holden, W, Chalg, ] , Miller, M, Hoffmaln, N O, \& Woodwand, $\mathrm{H}$ Studies of Carbohydrate Metabolısm during Ether Anesthesia Metabolısm 8827 (1959)

11 Greene, Nrcholas Inhalation Anesthetics and Carbohydrate Metabolism, p 94 Baltimore Williams and Wilkins (1963)

12 Hunter, A R Halothane and Blood Sugar Brit J Analsth 31490 (1959)

13 Keating, V, Patrick, S, \& AnN"amunthodo, H Halothane and Carbohydrate Metabolism Anaesthesia 14268 (1959)

14 Greene, Nicholas Ref 11, pp 108-111

15 Price, H L, Linde, H W, Jones, R E, Black, G W, \& Price, M L Sympathoadrenal Responses to General Anesthesia in Man and Therr Fielation to Hemodynamics Anesthesiology 20563 (1959)

16 Wasmuth, C R, Greig, V H, Homi, J, Moraca, P, Ibil, N, Bitte, E, \& Hale, D Methoxyflurane-A New Anesthetıc Agent Cleveland Clinı Quart 27174 (1960)

17 Dobkin, A \& Fedoruk, S Comparison of the Cardiovascular, Respiratory and Metabolic Effects of Methoxyflurane and Halothane in Dogs Anesthesiology 22355 (1961)

18 Hudon, F Methoxyflurane Canad Anaesth Soc J 8 544 (1961)

19 Wyant, G, Chang, G, \& Rapicaroli, E Methoxyflurane-A Laboratory and Clinical Study Canad Anaesth Soc J 8477 (1961)

20 Hennemann, D H \& Vandam, L D The Metabolic Consequences of Epinephrine and Insulin Administered during Ether Anesthesia in Man Anesthesiology 19104 (1958)

21 Hulme, N A \& Krantz, J C The Effect of Ethyl Ether on Oxıdative Phosphorylation in the Brain Anesthesiology 16627 (1955) 